Original Article

\title{
GREY WATER FARMING OF LADIES FINGER AND CLUSTER BEANS-INDUCES DIETARY TOXICITY?
}

\author{
DOKE SURAJ YASHWANT*', CHAVARE PRANAV MOHAN, BELVOTAGI VENKATRAO ADAVIRAO
}

Department of Quality Assurance, D. S. T. S. Mandal's College of Pharmacy, Solapur 413004

Email: doke.suraj@gmail.com

Received: 15 Feb 2017, Revised and Accepted: 10 May 2017

\section{ABSTRACT}

Objective: A large number of farmers are growing different vegetables and supplying them to the Solapur market. The majority of these farms are located on the banks of the "nullah", whose water is used for irrigation. From, a farm field in Degaon, a village on the Solapur-Mangalvedha road and on the bank of 'nullah' two fruit vegetables viz., Ladies Finger (Bhendi) and Cluster Beans (Gawar) are evaluated in the study. The purpose of this study was to analyse the presence of selected toxic non-essential heavy metals i.e. Arsenic (As), Cadmium (Cd), Chromium (Cr), Lead (Pb) and Mercury (Hg) in the two vegetables.

Methods: Atomic Absorption Spectrophotometer (AAS) was used for determining the concentration of heavy metals. Optimised wet acid digestion procedure was employed to solubilize the metals from the vegetable samples.

Results: The following concentrations (mg/kg) of the non-essential heavy metals were found in the edible parts of the Ladies Finger and Cluster Beans, respectively: Ladies Finger: As (16.07), Hg (16.77), Pb (1.148), Cr (17.14), Cd (0.704 mg/kg) and Cluster Beans: As (18.76), Hg (21.86), Pb (1.675), Cr (17.14), Cd (0.888 mg/kg). The study revealed the presence of all the chosen NEHMs in the vegetables. Cadmium levels in both Cluster Beans and Ladies Finger were below the maximum acceptable limit and hence fit for human consumption as per FSSAI standards As (1.1), Pb (1.0), $\mathrm{Cd}$ (1.5), Hg (1.0 ppm). Though unsafe as per WHO/FAO standards As (0.1), Pb (0.5), Cd (0.2), Cr (1.2), $\mathrm{Hg}(0.05 \mathrm{ppm})$.

Conclusion: The other three NEHMs levels were approximately 15 times more than the permitted levels and hence might pose danger on human consumption.

Keywords: AAS, Cluster Beans, Grey water, Ladies Finger, Non-essential heavy metals, WHO/FAO, FSSAI

(C) 2017 The Authors. Published by Innovare Academic Sciences Pvt Ltd. This is an open access article under the CC BY license (http://creativecommons.org/licenses/by/4.0/) DOI: http://dx.doi.org/10.22159/ijcpr.2017v9i4.20969

\section{INTRODUCTION}

Grey water is 'Wash water' or 'Stormwater" or 'Wastewater' or "Sewage water". It is all waste water apart from toilet wastes and food wastes. There are a significant difference between greywater and toilet waste water; it is also called as 'Blackwater' [1-3].

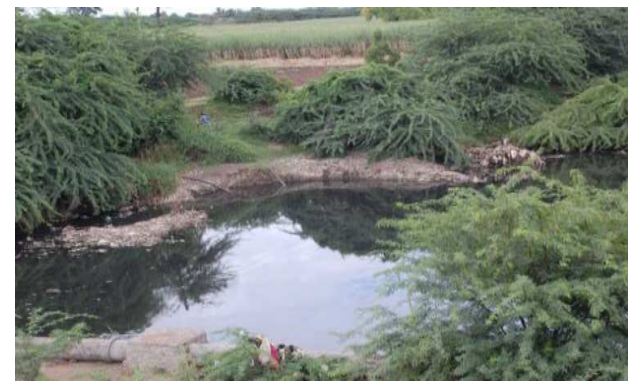

Fig. 1: A view of 'nullah' with grey waste water from Solapur city on Solapur-Mangalvedha road

\section{Role of vegetables on health}

Vegetables are the fresh and edible portions of herbaceous plants. They are essential food and highly beneficial for the maintenance of health and prevention of diseases. They contain valuable food ingredients like high carbohydrate, vitamin, mineral, fibre, antioxidants, metabolites and act as buffering agents for acidic substances which can be successfully utilized to build up and repair the body $[4,5]$. The recent Joint FAO/WHO expert consultation on diet, nutrition and the prevention of chronic diseases, recommended the intake of a minimum of $400 \mathrm{~g}$ of fruit and vegetables per day (excluding potatoes and other starchy tubers) for the prevention of chronic diseases such as heart diseases, cancer, diabetes [6].

Heavy metals in vegetables and their toxicity

The process of absorption of inorganic substances depends on the $\mathrm{pH}$ and type of soil. It has been observed that the conc. of minerals vary from place to place and from plant to plant and on the source of water also $[8,9]$. Non-essential heavy metals $\mathrm{Cr}, \mathrm{Cd}, \mathrm{Pb}, \mathrm{As}$, and $\mathrm{Hg}$ can get accumulated in commonly used vegetables i.e. Ladies Finger and Cluster Beans through the soil $[10,11]$.

Table 1: Permissible limits of heavy metals in vegetables as per WHO/FAO, FSSAI [7]

\begin{tabular}{lll}
\hline $\begin{array}{l}\text { Heavy } \\
\text { metal }\end{array}$ & $\begin{array}{l}\text { WHO/FAO permissible values } \\
\text { (mg/kg) }\end{array}$ & $\begin{array}{l}\text { Food safety and standards authority of India (FSSAI) parts per million (ppm) } \\
\text { metal }\end{array}$ \\
\hline $\mathrm{As}$ & 0.1 & 1.1 \\
$\mathrm{~Pb}$ & 0.5 & 1.0 \\
$\mathrm{Cd}$ & 0.2 & 1.5 \\
$\mathrm{Cr}$ & 1.2 & - \\
$\mathrm{Hg}$ & 0.05 & 1.0 \\
\hline
\end{tabular}


Table 2: Symptoms due to different heavy metals toxicity [12]

\begin{tabular}{ll}
\hline Heavy metals & Toxicity \\
\hline Arsenic & Acute poisoning, Cancer of lungs, GI damage-severe vomiting, diarrhea \\
Mercury & Malfunctioning of: nerves, kidneys and muscles, Neuromuscular changes (weakness, muscle atrophy, twitching), Emotional \\
& changes (mood swings, irritability, nervousness, etc.) \\
Cadmium & Nephrotoxicity, stomach irritation resulting in vomiting and diarrhea \\
Chromium & Damage to DNA and proteins \\
Lead & Loss of appetite, head-ache, hypertension, abdominal pain, renal dysfunction, fatigue, sleeplessness, arthritis, hallucinations, vertigo. \\
\hline
\end{tabular}

\section{Ladies finger (LF) (Okra) (Bhendi)}

'LF' contains vitamins and minerals as chief nutrients. It also contains a large amount of fiber, and has a unique profile of proteins. Okra mucilage has medicinal applications when used as a plasma replacement or blood volume expander [13].

\section{Cluster beans (CB) (Guar) (gawar)}

Cluster beans lower LDL, or bad cholesterol, levels thereby improving your heart health and lowering the risk of a heart attack. The iron in these beans increases body's hemoglobin production and allows blood to carry more oxygen around the body. Cluster beans have Vitamins A, B and $\mathrm{K}$, in addition to minerals like calcium, iron, folate and potassium [14].

\section{MATERIALS AND METHODS}

\section{Materials collection and location}

Ladies Finger and Cluster beans were collected from a farm near Degaon (Degaon-Kegaon road) village at around $10 \mathrm{kms}$ near Solapur on Solapur-Mangalvedha road. $\left(17.6721086{ }^{\circ} \mathrm{N}\right.$, $\left.75.8489531^{\circ} \mathrm{E}\right)[15]$.

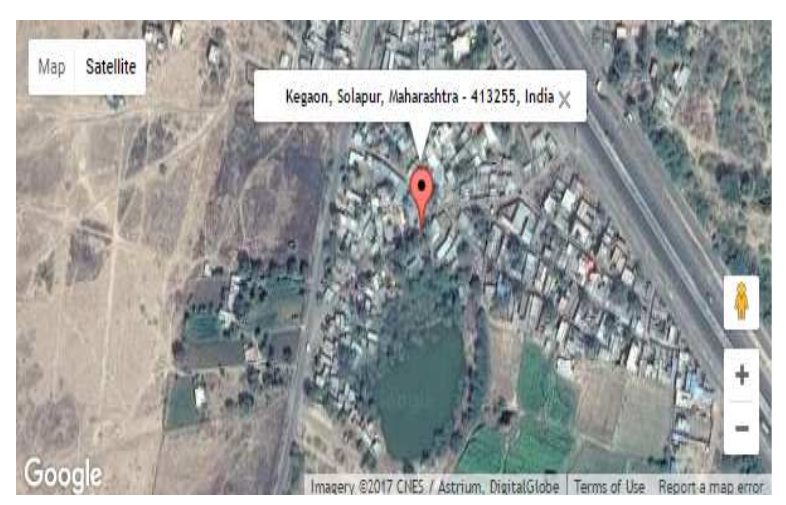

Fig. 2: Location of nullah (Degaon-Kegaon road)

Firstly, vegetable samples were washed with water to remove mud and dust and then finally rinsed with distilled water. Both the vegetable samples were sliced with the help a of knife into small pieces. The samples were dried in air under the sun for a few days.
They were ground by an electric grinder to small particle size and directly stored in fresh plastic containers for further analysis.

\section{Methods}

Wet acid digestion method as described by AOAC in 1990 was used in the study: $1.0 \mathrm{gm}$ each of dried sample was added to $10 \mathrm{ml}$ of conc. $\mathrm{HNO}_{3}$ in $50 \mathrm{ml}$ beaker and placed on the electric hot plate for 1 hour to get semi dried sample. Again $10 \mathrm{ml}$ of conc. $\mathrm{HNO}_{3}$ and $4 \mathrm{ml}$ of $\mathrm{H}_{2} \mathrm{O}_{2}$ were added and again kept on a hot plate and heated vigorously. The addition of $\mathrm{HNO}_{3}$ and $\mathrm{H}_{2} \mathrm{O}_{2}$ were continued till a colourless solution obtained. And its volume reduced up to $2-3 \mathrm{ml}$. It was cooled and filtered with the help of what man filter paper. The filtrate was stored in $10 \mathrm{ml}$ sample bottles or vials. It was diluted up to $25 \mathrm{ml}$ by de-ionized water before taking to Atomic Absorption Spectrometer. Metal contents in the prepared samples were analyzed using Atomic Absorption Spectrophotometer (iCE 3000, Thermo Scientific, USA) following the conditions described in AOAC (1990). Selected metals included Cadmium (Cd), Chromium (Cr), Arsenic (As), Lead ( $\mathrm{Pb}$ ), and Mercury (Hg). Calibrated standards were prepared from the commercially available stock solution in the form of an aqueous solution (1000 ppm). Highly purified de-ionized water was used for the preparation of working standards. All the glass apparatus used throughout the process of analytical work were immersed in 8N HNO3 overnight and washed with several changes of deionized water prior to use.

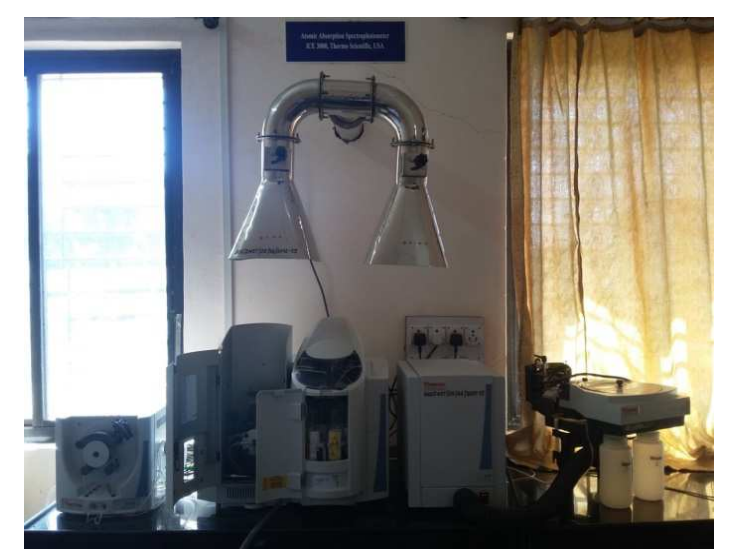

Fig. 3: Atomic absorption spectrophotometer (iCE 3000, thermo scientific, USA) (Solapur University, Solapur)

\section{RESULTS}

Table 3: Comparative conc. Vs absorbance data for $\mathrm{Cr}$ in the standard and $\mathrm{CB}$ samples

\begin{tabular}{llll}
\hline Sample ID & Absorbance & Rsd \% & Conc. mg/l or $\boldsymbol{\mu g} / \mathbf{m l}$ \\
\hline Cr Blank & 0.001 & 43.6 & 0.0000 \\
Cr Standard 1 & 0.070 & 2.2 & 10.0000 \\
Cr-1 & 0.005 & 7.4 & 0.5868 \\
Cr-2 & 0.004 & 1.9 & 0.4500 \\
Cr-3 & 0.004 & 16.4 & 0.4243 \\
Cr-4 & 0.006 & 6.9 & 0.6799 \\
Cr-5 & 0.005 & 3.0 & 0.5931 \\
Cr-6 & 0.005 & 7.7 & 0.5692 \\
\hline
\end{tabular}


Table 4: Comparative conc. Vs absorbance data for $\mathrm{Cr}$ in the standard and LF samples

\begin{tabular}{llll}
\hline Cr-1 & 0.006 & 8.2 & 0.6823 \\
Cr-2 & 0.006 & 5.1 & 0.7763 \\
Cr-3 & 0.007 & 7.7 & 0.8323 \\
Cr-4 & 0.004 & 9.8 & 0.5214 \\
Cr-5 & 0.003 & 14.5 & 0.3659 \\
Cr-6 & 0.003 & 13.9 & 0.2970 \\
\hline
\end{tabular}

\begin{tabular}{lll}
\hline Permissible limits & & Actual conc. of HM in sample \\
\hline As per WHO/FAO $(\mathrm{mg} / \mathrm{kg})$ & As per FSSAI $(\mathrm{mg} / \mathrm{kg})$ & $\mathrm{CB}$ \\
1.2 & - & $17.142 \mathrm{mg} / \mathrm{kg}$ \\
\hline
\end{tabular}

Table 5: Comparative conc. Vs absorbance data for As in the standard and CB samples

\begin{tabular}{llll}
\hline Sample ID & Absorbance & Rsd \% & Conc. $\mathbf{m g} / \mathbf{l ~ o r ~} \boldsymbol{\mu g} / \mathbf{m l}$ \\
\hline As Blank & 0.001 & 27.8 & 0.0000 \\
As Standard 1 & 0.373 & 0.8 & 40.0000 \\
As-1 & 0.010 & 10.6 & 1.1986 \\
As-2 & 0.008 & 4.3 & 0.9201 \\
As-3 & 0.007 & 8.0 & 0.8892 \\
As-4 & 0.008 & 5.4 & 0.9811 \\
As-5 & 0.005 & 2.2 & 0.6647 \\
As-6 & 0.005 & 26.4 & 0.6254 \\
\hline
\end{tabular}

Table 6: Comparative conc. Vs absorbance data for As in the standard and LF samples

\begin{tabular}{llll}
\hline As-1 & 0.002 & 53.7 & 0.3381 \\
As-2 & 0.007 & 7.3 & 0.8572 \\
As-3 & 0.009 & 3.2 & 1.0312 \\
As-4 & 0.009 & 3.0 & 1.0270 \\
As-5 & 0.007 & 3.0 & 0.8239 \\
As-6 & 0.007 & 6.2 & 0.8793 \\
\hline
\end{tabular}

\begin{tabular}{lll}
\hline Permissible limits & & Actual conc. of HM in the sample \\
\hline As per WHO/FAO $(\mathrm{mg} / \mathrm{kg})$ & As per FSSAI $(\mathrm{mg} / \mathrm{kg})$ & $\mathrm{CB}$ \\
0.1 & 1.1 & $18.766 \mathrm{mg} / \mathrm{kg}$ \\
\hline
\end{tabular}

Table 7: Comparative conc. Vs absorbance data for $\mathrm{Cd}$ in the standard and $\mathrm{CB}$ samples

\begin{tabular}{llll}
\hline Sample ID & Absorbance & Rsd \% & Conc. $\mathbf{~ m g / l ~ o r ~} \boldsymbol{\mu g} / \mathbf{m l}$ \\
\hline Cd Blank & 0.005 & 27.6 & 0.0000 \\
Cd Standard 1 & 1.360 & 0.2 & 10.0000 \\
Cd-1 & 0.006 & 12.8 & 0.0050 \\
Cd-2 & 0.005 & 12.9 & 0.0024 \\
Cd-3 & 0.004 & 14.5 & 0.0048 \\
Cd-4 & 0.005 & 5.0 & 0.0034 \\
Cd-5 & 0.005 & 7.2 & 0.0015 \\
Cd-6 & 0.004 & 6.7 & 0.0088 \\
\hline
\end{tabular}

Table 8: Comparative conc. Vs absorbance data for Cd in the standard and LF samples

\begin{tabular}{llll}
\hline Cd-1 & & 10.3 & 0.0066 \\
Cd-2 & 0.004 & 2.3 & 0.0062 \\
Cd-3 & 0.004 & 5.8 & 0.0147 \\
Cd-4 & 0.003 & 13.1 & 0.0276 \\
Cd-5 & 0.001 & 12.2 & 0.0403 \\
Cd-6 & 0.000 & $>99$ & 0.1155 \\
\hline
\end{tabular}

\section{Permissible limits}

As per WHO/FAO $(\mathrm{mg} / \mathrm{kg})$

0.2

As per FSSAI (mg/kg)

1.5
Actual conc. of HM in the sample CB

$0.888 \mathrm{mg} / \mathrm{kg}$
LF

$0.704 \mathrm{mg} / \mathrm{kg}$ 
Table 9: Comparative conc. Vs absorbance data for $\mathrm{Pb}$ in the standard and CB samples

\begin{tabular}{llll}
\hline Sample ID & Absorbance & Rsd \% & Conc. $\mathbf{~ m g} / \mathbf{l ~ o r ~} \boldsymbol{\mu g} / \mathbf{m l}$ \\
\hline $\mathrm{Pb}$ Blank & 0.000 & $>99$ & 0.0000 \\
$\mathrm{~Pb}$ Standard 1 & 0.544 & 0.3 & 10.0000 \\
$\mathrm{~Pb}-1$ & 0.003 & 5.9 & 0.0556 \\
$\mathrm{~Pb}-2$ & 0.007 & 2.3 & 0.1366 \\
$\mathrm{~Pb}-3$ & 0.003 & 8.8 & 0.0575 \\
$\mathrm{~Pb}-4$ & 0.005 & 2.0 & 0.1028 \\
$\mathrm{~Pb}-5$ & 0.003 & 7.1 & 0.0543 \\
$\mathrm{~Pb}-6$ & 0.001 & 21.9 & 0.0307 \\
\hline
\end{tabular}

Table 10: Comparative conc. Vs absorbance data for $\mathrm{Pb}$ in the standard and LF samples

\begin{tabular}{llll}
\hline $\mathrm{Pb}-1$ & 0.001 & 5.6 & 0.0091 \\
$\mathrm{~Pb}-2$ & 0.003 & 9.3 & 0.0614 \\
$\mathrm{~Pb}-3$ & 0.003 & 13.2 & 0.0604 \\
$\mathrm{~Pb}-4$ & 0.004 & 3.2 & 0.0832 \\
$\mathrm{~Pb}-5$ & 0.002 & 13.6 & 0.0451 \\
$\mathrm{~Pb}-6$ & 0.002 & 5.0 & 0.0469 \\
\hline
\end{tabular}

\begin{tabular}{lll}
\hline Permissible limits & & Actual conc. of HM in the sample \\
\hline As per WHO/FAO $(\mathrm{mg} / \mathrm{kg})$ & As per FSSAI $(\mathrm{mg} / \mathrm{kg})$ & $\mathrm{CB}$ \\
0.5 & 1.0 & $1.675 \mathrm{mg} / \mathrm{kg}$ \\
\hline
\end{tabular}

Table 11: Comparative conc. Vs absorbance data for $\mathrm{Hg}$ in the standard and CB samples

\begin{tabular}{llll}
\hline Sample ID & Absorbance & Rsd \% & Conc. mg/l or $\boldsymbol{\mu g} / \mathbf{m l}$ \\
\hline Hg Blank & 0.107 & $>99$ & 0.0000 \\
Hg Standard 1 & 0.678 & 0.5 & 300.0000 \\
Hg-1 & 0.006 & 5.8 & 2.6232 \\
Hg-2 & 0.002 & 2.6 & 0.9867 \\
Hg-3 & 0.000 & 53.8 & 0.2661 \\
Hg-4 & 0.000 & 36.6 & 0.3035 \\
Hg-5 & 0.001 & 1.1 & 0.2302 \\
Hg-6 & 0.008 & 6.1 & 51.9592 \\
\hline
\end{tabular}

Table 12: Comparative conc. Vs absorbance data for $\mathrm{Hg}$ in the standard and LF samples

\begin{tabular}{llll}
\hline Hg-1 & 0.005 & 2.7 & 53.4478 \\
Hg-2 & 0.003 & 1.8 & 54.0988 \\
Hg-3 & 0.003 & 7.0 & 54.0740 \\
Hg-4 & 0.004 & 6.3 & 54.0163 \\
Hg-5 & 0.003 & 8.1 & 54.4573 \\
Hg-6 & 0.002 & 8.9 & 54.6968 \\
\hline
\end{tabular}

\begin{tabular}{lll}
\hline Permissible limits & & Actual conc. of HM in sample \\
\hline As per WHO/FAO $(\mathrm{mg} / \mathrm{kg})$ & As per FSSAI $(\mathrm{mg} / \mathrm{kg})$ & $\mathrm{CB}$ \\
0.05 & 1.0 & $21.865 \mathrm{mg} / \mathrm{kg}$ \\
\hline
\end{tabular}

Table 13: Consolidated list of conc. of HMs in CB and LF

\begin{tabular}{llll}
\hline Metals & Heavy metals conc. in CB (Gawar) (mg/kg) & Metals & Heavy metals conc. in LF (Bhendi) (mg/kg) \\
\hline $\mathrm{As}$ & 18.77 & $\mathrm{As}$ & 16.07 \\
$\mathrm{Cd}$ & 0.89 & $\mathrm{Cd}$ & 0.70 \\
$\mathrm{Cr}$ & 17.14 & $\mathrm{Cr}$ & 17.14 \\
$\mathrm{~Pb}$ & 1.68 & $\mathrm{~Pb}$ & 1.15 \\
$\mathrm{Hg}$ & 21.87 & $\mathrm{Hg}$ & 16.78 \\
\hline
\end{tabular}

\section{DISCUSSION}

The AOAC method (1990) of estimation of heavy metals in organic samples using AAS yielded the results as presented the above fig. and tables. From the results, following information could be derived

\section{Heavy metals conc. in cluster beans}

Of the five NEHMs evaluated in $C B$ all the five metals could be detected in the samples chosen. However, of the five, three heavy metals viz., As, $\mathrm{Cr}$, and $\mathrm{Hg}$ were seen in exceedingly high conc. of $18.77,17.14$ and
$21.87 \mathrm{mg} / \mathrm{kg}$ conc. respectively. Though, $\mathrm{Cd}(0.89 \mathrm{mg} / \mathrm{kg})$ and $\mathrm{Pb}(1.68$ $\mathrm{mg} / \mathrm{kg}$ ) were in relatively low conc. these two also were above their permissible limits of 0.2 and $1.0 \mathrm{mg} / \mathrm{kg}$ of the sample.

\section{Heavy metal conc. in ladies finger}

Of the five NEHMs evaluated in $L F$ all the five metals could be detected in the samples chosen. However, of the five, three heavy metals viz., As, $\mathrm{Cr}$, and $\mathrm{Hg}$ were seen in exceedingly high conc. of $16.07,17.14$ and $16.78 \mathrm{mg} / \mathrm{kg}$ conc. respectively. Though $\mathrm{Cd}(0.70 \mathrm{mg} / \mathrm{kg})$ and $\mathrm{Pb}(1.15$ 
$\mathrm{mg} / \mathrm{kg}$ ) were in relatively low conc., these two also were above their permissible limits of 0.2 and $1.0 \mathrm{mg} / \mathrm{kg}$ of the sample.

\section{CONCLUSION}

The results indicate that all the non-essential heavy metals are chosen in this study viz., $\mathrm{As}, \mathrm{Cd}, \mathrm{Cr}, \mathrm{Hg}$ and $\mathrm{Pb}$ were found to exist in both the vegetable samples. The concentration of $\mathrm{As}, \mathrm{Hg}$ and $\mathrm{Cr}$ were found in excessively high amounts whereas, $\mathrm{Cd}$ and $\mathrm{Pb}$ were just above the permitted limits. This may be pointing towards possible contamination of 'nullah water' with wastes from automotive garages which might lead to elevated lead and mercury levels. But, it is interesting to see that the lead and cadmium conc. in both the vegetables were low indicating either inability of the plant to accumulate these NEHMs or their absence in soil/water. It is also interesting to note that the absorption pattern of all the five metals was similar in both CB and LF. This means the existence of an unfavourable set of conditions for the cultivation of these two vegetable crops. Further, consumption of $\mathrm{CB}$ and LF might also potentially exhibit toxicity symptoms of $\mathrm{As}, \mathrm{Cr}$ and $\mathrm{Hg}$ on short-term treatment and $\mathrm{Cd}$ and $\mathrm{Pb}$ toxicity on long-term treatment. It might also indicate that the conditions of cultivation i.e., soil nature, water source are both unsuitable for the cultivation of the two plants. So, it might be better to substitute these two plants from others which don't accumulate the NEHMs under study. Alternatively, it would also be possible to follow remediation of soil to avoid the uptake of HMs by either changing their oxidation status or by changing soil $\mathrm{pH}$.

\section{ACKNOWLEDGEMENT}

I am indebted to the rich source, deep inspire and my esteemed guide Dr. Belvotagi Venkatrao Adavirao, Associate Professor, Department Of Quality Assurance, D. S. T. S. Mandal's College of Pharmacy, Solapur. His words of advice have been etched in my heart and I always endeavour to hold up his ideas. It's my pleasure to express sincere thanks to Prin. R. Y. Patil sir, Principal, D. S. T. S. Mandal's College of Pharmacy, Solapur and Dr. Kalshetti sir, HOD, Department of Quality Assurance, D. S. T. S. Mandal's College Of Pharmacy, Solapur. I am immensely thankful to, Dr. A. A. Ghanwat sir (Co-ordinator, Instrumentation centre), Dr. M. A. Kulkarni sir (Instrument Expert), R. C. Pawar sir (Laboratory Assistant) Solapur University, Solapur for assisting in Atomic Absorption Spectrophotometric measurements.

\section{CONFLICT OF INTERESTS}

Declare none

\section{REFERENCES}

1. Morel A. Greywater treatment on a household level in developing countries-a state of the art review. Semester work of barba raimhof and joëlle mühlemann; 2005. p. 1-98.
2. Lone AH, Lal EP, Thakur S. Accumulation of heavy metals on soil and vegetable crops grown on sewage and tube well water irrigation. Sci Res Essays 2013;8:2187-93.

3. Deribachew B, Made M, Nigussie-Dechassa R, Taddesse AM. Selected heavy metals in some vegetables produced through wastewater irrigation and their toxicological implications in eastern Ethiopia. Afr J Food Agric Nutr Dev 2015;15:10013-32.

4. Akan JC, Kolo BG, Yikala BS, Ogugbuaja VO. Determination of some heavy metals in vegetable samples from biu local government Area, Borno State, North Eastern Nigeria. Int J Environ Monit Anal 2013;1:40-6.

5. Elbagermi MA, Edwards HGM, Alajtal AI. Monitoring of heavy metal content in fruits and vegetables collected from production and market sites in the misurata Area of Libya. Int Scholarly Res Network (ISRN) Anal Chem 2012:1-6. http://dx.doi.org/10.5402/2012/827645

6. Joint FAO/WHO Workshop on Fruit and Vegetables for Health (Kobe, Japan) Fruit and vegetables for health: Report of a Joint FAO/WHO Workshop, Kobe, Japan; 2004.

7. Ogunkunle ATJ, Bello OS, Ojofeitimi OS. Determination of heavy metal contamination of street-vended fruits and vegetables in Lagos state, Nigeria. Int Food Res J 2014;21:2115-20.

8. Hough RL, Breward N, Young SD. Assessing potential risk of heavy metal exposure from consumption of home-produced vegetables by Urban Populations. Environ Health Perspectives 2004;112:215-21.

9. Doherty VF, Sogbanmu TO, Kanife UC, Wright O. Heavy metals in vegetables collected from selected farm and market sites in Lagos, Nigeria, Global. Adv Res J Environ Sci Toxicol 2012;1:137-42.

10. Ramteke S, Sahu BL, Dahariya NS, Patel KS, Blazhev B, Matini L. Heavy metal contamination of vegetables. J Environ Protection 2016;7:996-1004.

11. Labhade KR. Assessment of heavy metal contamination in vegetables grown in and Around Nashik City, Maharashtra State, India. IOSR J Appl Chem 2013;5:9-14.

12. Tchounwou PB, Yedjou CG, Patlolla AK, Sutton DJ. Heavy metals toxicity and the environment. NIH Public Access 2012;101:133-64.

13. Gemede HF, Ratta N, Haki GD, Woldegiorgis AZ, Beyene F. Nutritional quality and health benefits of okra (Abelmoschus esculentus): a review. J Food Process Technol 2015;6:458.

14. www.indiatimes.com/health/healthyliving/health-benefits-ofcluster-beans-guar-241906.html [Last accessed on 29 Mar 2017]

15. https://www.google.co.in/maps/@17.6721086,75.8489531,19 $4 \mathrm{~m} /$ data. [Last accessed on 01 Apr 2017]

\section{How to cite this article}

- Doke Suraj Yashwant, Chavare Pranav Mohan, Belvotagi Venkatrao Adavirao. Grey water farming of ladies finger and cluster beansinduces dietary toxicity? Int J Curr Pharm Res 2017;9(4):104-108. 